\title{
Partha Kar: Is genuine patient choice possible in the NHS?
}

\author{
Partha Kar consultant in diabetes and endocrinology \\ Portsmouth Hospitals NHS Trust
}

Patient choice. Patient empowerment. As doctors we may say that we welcome, want, or support these things—but how much do we mean it? How much does the system actually allow it? How often are we doing any more than the bare minimum to tick a box, in terms of providing patient choice? The uncomfortable answer is that we've only just moved beyond paying it lip service.

But giving choice to patients can be tricky. If we say that the patient knows best, we're bound to spark a debate with colleagues. And the extent to which any request from a patient is based on reliable information can be a worry. Is the request driven by stories in the media? Is it the result of some ill-thought-out national campaign? Has there been some sort of industry influence?

To make things harder, we're in an era where treatments are too often rationed or denied. And, once a patient is denied a treatment, the conversations that follow aren't always sensible or rational. Patients think about the care being offered and, quite rightly, want the very best available. Any decision not to provide care or to prioritise resources, even when that decision is based on sound evidence, is seen as a denial of care, creating a divide between patients and healthcare workers.

Some healthcare professionals try to ensure that they have conversations with patients to explain these decisions. But most don't have enough time to explore all of the issues raised, and it may seem easier to simply shut the patient out of the decision.
When patients are offered a choice of centre to be referred to, they may want to know what level of care the different centres provide. Without inside knowledge of the NHS, is there an online tool or directory to help them decide? No-the decision will have to be based on the belief that the local hospital is good enough, without much information to support this.

So, where does patient choice actually fit into all of this? Is it compatible with a system that provides care free at the point of delivery? If GPs are under pressure to reduce referrals to secondary care, does that affect whether patients can choose the type of care they receive?

We're not really providing patients with choice if the treatments they choose aren't available to them or if they don't have information about those that are. We need to be bold enough to have these discussions openly with patients and fellow professionals-but how ready are we, as a system, to do that? Personally, I think that the time is right and that most patients do appreciate what's not possible, in a tax funded system with competing interests and a finite financial pot.

Competing interests: I am associate national clinical director for diabetes with NHS England.

Provenance and peer review: Commissioned; not externally peer reviewed.

Published by the BMJ Publishing Group Limited. For permission to use (where not already granted under a licence) please go to http://group.bmj.com/group/rights-licensing/ permissions 